\begin{tabular}{|c|c|c|c|}
\hline \multirow{2}{*}{$\begin{array}{r}\text { Case Reports in } \\
\text { Gastroenterology }\end{array}$} & \multicolumn{2}{|c|}{ Case Rep Gastroenterol 2017;11:651-654 } & \multirow[b]{2}{*}{$\begin{array}{l}\text { Karger } \\
\text { Openaccess }\end{array}$} \\
\hline & $\begin{array}{l}\text { DOI: 10.1159/000479309 } \\
\text { Published online: October 30, } 2017\end{array}$ & $\begin{array}{l}\text { ( } 2017 \text { The Author(s) } \\
\text { Published by S. Karger AG, Basel } \\
\text { www.karger.com/crg }\end{array}$ & \\
\hline & $\begin{array}{l}\text { This article is licensed under the } \\
\text { International License (CC BY-NC) } \\
\text { Usage and distribution for commer }\end{array}$ & $\begin{array}{l}\text { mons Attribution-NonCommercial } 4.0 \\
\text { ger.com/Services/OpenAccessLicense). } \\
\text { quires written permission. }\end{array}$ & \\
\hline
\end{tabular}

\title{
Internal Hernia into the Treitz Fossa after Pancreaticoduodenectomy
}

\author{
Takahiro Yamanaka $^{a} \quad K^{2}$ enichiro Araki ${ }^{a}$ Kei Hagiwara ${ }^{a}$ Norihiro Ishii $^{a}$ \\ Mariko Tsukagoshi ${ }^{a}$ Takamichi Igarashi $^{a} \quad$ Akira Watanabe $^{\mathrm{a}}$ \\ Norio Kubo ${ }^{a}$ Hiroyuki Kuwano $^{b}$ Ken Shirabe $^{a}$ \\ ${ }^{a}$ Department of Hepatobiliary and Pancreatic Surgery, Gunma University Graduate School \\ of Medicine, Maebashi, Japan; 'bepartment of General Surgical Science (Surgery I), \\ Gunma University Graduate School of Medicine, Maebashi, Japan
}

\section{Keywords}

Pancreaticoduodenectomy $\cdot$ Internal hernia $\cdot$ Treitz fossa

\begin{abstract}
The development of an internal hernia into the Treitz fossa after pancreaticoduodenectomy has not been previously reported. We herein present such a case with a brief review of the literature. A 43-year-old man who had undergone pancreaticoduodenectomy with reconstruction of the digestive tract by the Child method at our hospital 7 months previously presented with abdominal pain. Computed tomography showed intestinal ileus with formation of a small intestinal loop that was suspected to be an internal hernia. Intraoperatively, we found that the dilated small intestine had entered the upper side of the abdomen from the ligament of Treitz. We detached the intestine from the hernia and placed it in its normal position. The ligament of Treitz at the hernia orifice was closed with sutures. The patient remained in good health and was discharged from the hospital 18 days after the second operation. Suturing of the Treitz fossa at the time of pancreaticoduodenectomy may be important to prevent the formation of an internal hernia.

(C) 2017 The Author(s) Published by S. Karger AG, Basel
\end{abstract}




\section{Background}

Pancreaticoduodenectomy (PD) is the first-choice surgical procedure for patients with a malignant neoplasm in the periampullary region. The morbidity rate after PD remains higher than that after other surgical procedures for treatment of gastroenterological cancers [1]. We treated a patient with internal hernia of the Treitz fossa after PD for a pancreatic tumor. No previous reports in the literature have described the development of an internal hernia into the Treitz fossa after PD. We herein present such a case with a brief review of the literature.

\section{Case Presentation}

A 43-year-old man with abdominal pain presented to our hospital. He had undergone PD with reconstruction of the digestive tract by the Child method at our hospital 7 months previously for treatment of pancreatic schwannoma. Physical examination revealed epigastric pain, a body temperature of $36.7^{\circ} \mathrm{C}$, pulse of $77 / \mathrm{min}$, and blood pressure of $171 / 21 \mathrm{~mm}$ Hg. Laboratory data on admission to our hospital were as follows: white blood cell count, $11,900 / \mu \mathrm{L}$; red blood cell count, $577 \times 10^{4} / \mu \mathrm{L}$; hemoglobin, $16.7 \mathrm{~g} / \mathrm{dL}$; hematocrit, $47.5 \%$; platelets, $21.3 \times 10^{4} / \mu \mathrm{L}$; total protein, $7.2 \mathrm{~g} / \mathrm{dL}$; albumin, $4.7 \mathrm{~g} / \mathrm{dL}$; total bilirubin, $2.0 \mathrm{mg} / \mathrm{dL}$; aspartate aminotransferase, $15 \mathrm{IU} / \mathrm{L}$; alanine aminotransferase, $20 \mathrm{IU} / \mathrm{L}$; alkaline phosphatase, $377 \mathrm{IU} / \mathrm{L} ; \gamma$-glutamyl transferase, $14 \mathrm{IU} / \mathrm{L}$; amylase, $59 \mathrm{U} / \mathrm{L}$; creatine kinase, $44 \mathrm{IU} / \mathrm{L}$; lactate dehydrogenase, $209 \mathrm{IU} / \mathrm{L}$; blood urea nitrogen, $21 \mathrm{mg} / \mathrm{dL}$; creatinine, $0.71 \mathrm{mg} / \mathrm{dL}$; $\mathrm{Na}, 137 \mathrm{mEq} / \mathrm{dL} ; \mathrm{K}, 4.0 \mathrm{mEq} / \mathrm{dL} ; \mathrm{Cl}, 99 \mathrm{mEq} / \mathrm{dL}$; and C-reactive protein, $0.48 \mathrm{mg} / \mathrm{dL}$. Computed tomography showed intestinal ileus with the formation of a small intestinal loop that was suspected to be an internal hernia (Fig. 1). Intraoperatively, we found that the dilated small intestine had entered the upper side of the abdomen from the ligament of Treitz. We detached the intestine from the hernia and placed it in its normal position. The intestine was not damaged, and intestinal resection was not required. The ligament of Treitz at the hernia orifice was closed with sutures. The patient remained in good health and was discharged from the hospital 18 days after the second operation.

\section{Discussion}

PD continues to be associated with considerable morbidity, and postoperative complications occur in about $40 \%$ of patients [1-3]. Many reports have described pancreatic fistula, paralytic ileus, and other complications after PD; however, none have described the development of an internal hernia. Closure of both mesenteric and Petersen's defects is reportedly associated with a low incidence of internal herniation following laparoscopic Roux-en-Y gastric bypass [4]. Selective closure of the mesenteric defect during left-sided restorative procedures in patients undergoing an initial laparoscopic colorectal surgery may also be considered [5]. It may be important to suture the Treitz fossa at the time of PD to prevent internal hernia formation. 
Yamanaka et al.: Internal Hernia into the Treitz Fossa after Pancreaticoduodenectomy

\section{Conclusion}

We experienced a case involving a patient with an internal hernia into the Treitz fossa 7 months after PD for a pancreatic tumor. Suturing of the Treitz fossa at the time of PD may be important to prevent the development of an internal hernia.

\section{Statement of Ethics}

Approval from the Ethics Committee was not required for this case report. Written informed consent was obtained from the patient for publication of this case report and any accompanying images.

\section{Disclosure Statement}

The authors declare that they have no financial support in association with this case report. The authors declare that they have no competing interests.

\section{References}

1 Aoki S, Miyata H, Konno H, Gotoh M, Motoi F, Kumamaru H, Wakabayashi G, Kakeji Y, Mori M, Seto Y, Unno M: Risk factors of serious postoperative complications after pancreaticoduodenectomy and risk calculators for predicting postoperative complications: a nationwide study of 17,564 patients in Japan. J Hepatobiliary Pancreat Sci 2017;24:243-251.

-2 Schmidt CM, Powell ES, Yiannoutsos CT, Howard TJ, Wiebke EA, Wiesenauer CA, Baumgardner JA, Cummings OW, Jacobson LE, Broadie TA, Canal DF, Goulet RJ Jr, Curie EA, Cardenes H, Watkins JM, Loehrer PJ, Lillemoe KD, Madura JA: Pancreaticoduodenectomy: a 20-year experience in 516 patients. Arch Surg 2004;139:718-725;discussion 725-727.

3 Kim H, Chung JK, Ahn YJ, Lee HW, Jung IM: The 13-year experience of performing pancreaticoduodenectomy in a mid-volume municipal hospital. Ann Surg Treat Res 2017;92:73-81.

-4 Geubbels N, Lijftogt N, Fiocco M, van Leersum NJ, Wouters MW, de Brauw LM: Meta-analysis of internal herniation after gastric bypass surgery. Br J Surg 2015;102:451-460.

5 Toh JW, Lim R, Keshava A, Rickard MJ: The risk of internal hernia or volvulus after laparoscopic colorectal surgery: a systematic review. Colorectal Dis 2016;18:1133-1141. 

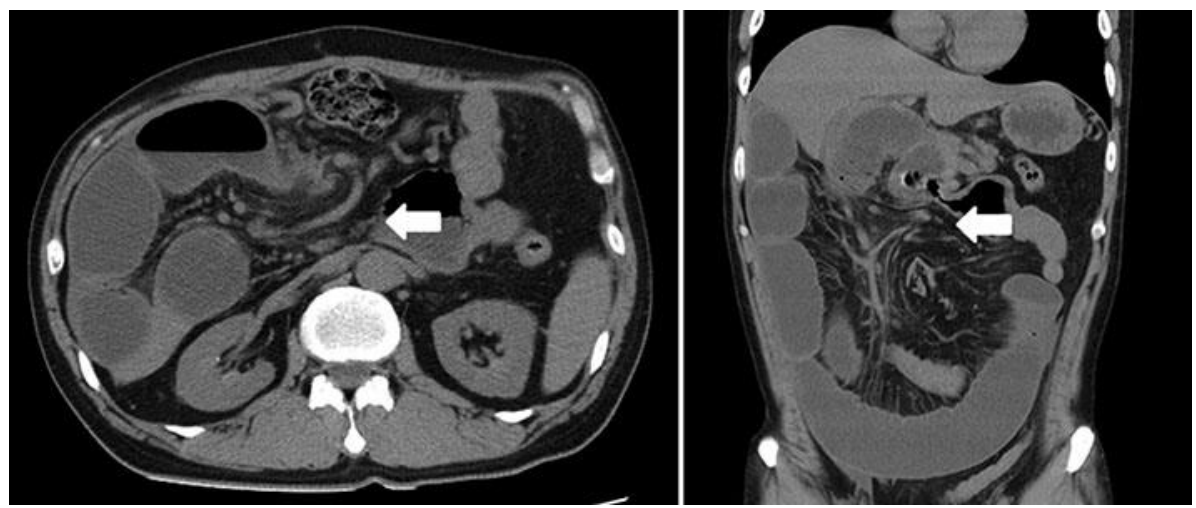

Fig. 1. Computed tomography examination of the internal hernia. The small intestine entered the upper side of the abdomen from the ligament of Treitz. The orifice of the internal hernia is indicated by arrows. 